\title{
PROFIL STRATEGI PEMBELAJARAN BAHASA JEPANG DI KELAS 4 SD SARASWATI TABANAN
}

\author{
N. P. Y. Armini ${ }^{1}$, D. M. S. Mardani ${ }^{2}$, G. S. Hermawan ${ }^{3}$ \\ 123 Jurusan Pendidikan Bahasa Jepang, Universitas Pendidikan Ganesha, Singaraja,Bali \\ e-mail:armini.putu@undiksha.ac.id, desak.mardani@undiksha.ac.id, \\ satya.hermawan@undiksha.ac.id.
}

\begin{abstract}
Abstrak
Penelitian ini bertujuan untuk mendeskripsikan (1) sasaran pembelajaran bahasa Jepang di kelas 4 SD Saraswati Tabanan, (2) strategi pembelajaran yang digunakan oleh guru bahasa Jepang di kelas 4 SD Saraswati Tabanan, (3) faktor-faktor yang mendasari penggunaan strategi pembelajaran bahasa Jepang, dan (4) kendala-kendala yang dihadapi dalam kegiatan pembelajaran bahasa Jepang di kelas 4 SD Saraswati Tabanan. Subjek penelitian ini adalah guru bahasa Jepang di kelas 4 SD Saraswati Tabanan. Pengumpulan data dilakukan dengan metode observasi, wawancara, dan dokumentasi, kemudian dianalisis dengan metode deskriptif kualitatif. Hasil penelitian menunjukkan bahwa (1) Sasaran pembelajaran bahasa Jepang di kelas 4 SD Saraswati Tabanan yaitu agar siswa mampu mengembangkan keterampilan dasar berbahasa Jepang yang meliputi aspek mendengarkan, berbicara, membaca, dan menulis; (2) Strategi pembelajaran yang digunakan dalam pembelajaran bahasa Jepang di kelas 4 SD Saraswati Tabanan yaitu strategi drill, tanya jawab, dan pemberian tugas; (3) Guru bahasa Jepang di kelas 4 SD Saraswati Tabanan menggunakan strategi pembelajaran berdasarkan karakteristik siswa dan kondisi siswa di dalam kelas; dan (4) Kendala yang dihadapi guru bahasa Jepang di kelas 4 SD Saraswati Tabanan yaitu kendala pemilihan bahan ajar dan kendala alokasi waktu.
\end{abstract}

Kata kunci : pembelajaran, profil, strategi pembelajaran

\section{要旨}

本研究の目的は、(1) タバナンサラスワテイ小学校4年生の日本語学習目標、(2) タバナンサラスワテイ 小学校4年生の日本語教師が使用するストラテジー、(3) 当校日本語教師が使用するストラテジーの要 因、(4) 日本語を担当する教師が、授業の際に直面する問題点を明らかにすることである。研究の対 象は、タバナンサラスワテイ小学校4年生の日本語教師である。調査方法は、観察、インタビュー及 び、文献調查である。収集したデータを定性記述法により分析した。分析した結果は、(1) 日本語学 習の目標は、聞く力・話す力・読む力・書く力という4つの能力において、日本語能力を伸ばすこと ができることである、(2) 日本語学習の目標を達成するためのストラテジーは、ドリルと応答練習と タクスである、(3) 日本語における学習使用の要因は、生徒の特性と教室の生徒の状態である、(4) 日 本語ご障害は、教材の選択と時間割である。

キーヨード：学習、紹介、ストラテジー

\section{Pendahuluan}

Dalam proses pembelajaran terdapat beberapa komponen penting yang saling mempengaruhi antara satu dengan yang lainnya. Proses pembelajaran akan berjalan efektif apabila komponen-komponen tersebut dapat berinteraksi dengan baik. Guru diharapkan mengetahui dan memahami hakikat pembelajaran termasuk strategi pembelajaran. Dengan adanya strategi yang jelas, proses pembelajaran akan terarah sehingga guru memiliki pedoman bertindak sistematis dalam pelaksanaan pembelajaran dan mempermudah proses pembelajaran.

Pada umumnya, bahasa Jepang mulai diperkenalkan pada jenjang SMP atau SMA, dan sudah terdapat banyak strategi pembelajaran yang dikembangkan oleh ahli bahasa. Namun kondisi berbeda ketika bahasa Jepang diperkenalkan pada jenjang SD. Strategi yang digunakan pada tingkat SMP atau SMA sama dengan yang di SD, perbedaannya terletak 
pada masing-masing tahapannya. Selain itu, karakteristik siswa juga menjadi faktor utama pemilihan strategi pembelajaran yang akan digunakan.

Di Bali, terdapat beberapa SD yang menyelenggarakan pembelajaran bahasa Jepang, salah satunya SD Saraswati Tabanan yang berlokasi di Tabanan dan merupakan satu-satunya SD di kabupaten Tabanan yang menyelenggarakan pembelajaran bahasa Jepang. Sekolah tersebut menerapkan kurikulum 2013 dan bahasa Jepang diberikan kepada siswa dari kelas 4, 5, dan 6 . Selain itu, setiap tahun guru bahasa Jepang di sekolah tersebut mengajak siswanya untuk mengunjungi festival kebudayaan Jepang yang diselenggarakan di Bali agar siswa mengetahui beberapa kebudayaan Jepang.

Berdasarkan observasi dan wawancara yang dilakukan, siswa kelas 4 baru pertama kalinya memperoleh pembelajaran bahasa Jepang, namun pembelajarannya berlangsung dengan kondusif sehingga pembelajaran berjalan dengan efektif. Selain itu siswa juga aktif bertanya kepada guru apabila terdapat hal-hal yang belum jelas atau dimengerti. Hal tersebut sejalan dengan pendapat Matakupan (1994) yang menyatakan bahwa siswa sekolah dasar kelas tinggi merupakan siswa yang memiliki rasa ingin tahu yang tinggi dan memiliki minat untuk belajar sesuatu yang baru. Materi di kelas 4 tidak sebatas pengenalan kosakata, tetapi penggunaan kosakata dan kalimat serta agar siswa memahami makna dari kosakata maupun kalimat tersebut. Proses pembelajaran yang berlangsung kondusif tentunya berkaitan dengan pemilihan strategi pembelajaran dan cara guru mengatasi kendala-kendala yang terjadi.

Penelitian tentang strategi pembelajaran bahasa Jepang sudah pernah dilakukan pada tahun 2015 oleh Dewi di kota Singaraja. Penelitian tersebut difokuskan pada penggunaan strategi pembelajaran pada tingkat SMA. Hasil dari penelitian tersebut yaitu guru menggunakan strategi pembelajaran disesuaikan berdasarkan karakteristik siswa, keadaan siswa di kelas, dan materi yang diajarkan.

Dari hasil observasi dan wawancara yang telah dilakukan, maka dipilih penelitian yang berjudul "Profil Strategi Pembelajaran Bahasa Jepang di Kelas 4 SD Saraswati Tabanan".

Dari latar belakang yang telah dipaparkan, dapat dirumuskan permasalahan yaitu sebagai berikut.

1. Apa sasaran pembelajaran bahasa Jepang pada kelas 4 SD Saraswati Tabanan ?

2. Apa dan bagaimana strategi pembelajaran yang digunakan oleh guru untuk mencapai sasaran pembelajaran bahasa Jepang pada kelas 4 SD Saraswati Tabanan ?

3. Apa saja faktor-faktor yang mendasari penggunaan strategi dalam pembelajaran bahasa Jepang pada kelas 4 SD Saraswati Tabanan?

4. Apa kendala-kendala yang dihadapi dalam kegiatan pembelajaran bahasa Jepang di kelas 4 SD Saraswati Tabanan?

Bahasa Jepang dipelajari sebagai bahasa asing, yaitu bahasa yang belum pernah dikenal oleh peserta didik. Uno (2007) menyatakan bahwa pembelajaran diartikan sebagai suatu proses interaksi antara peserta belajar dengan pengajar atau instruktur atau sumber belajar pada suatu lingkungan belajar untuk mencapai tujuan belajar tertentu. Proses yang terjadi dalam pembelajaran mengubah siswa dari tidak tahu menjadi tahu dan mengubahnya kearah yang lebih baik. Seseorang yang mengalami proses pembelajaran tentunya mengalami perubahan, khususnya dalam segi pengetahuan. Dalam teori taksonomi bloom (dalam Dimyati dan Mudjiono, 2006), terdapat enam jenis ranah pengetahuan yang harus dicapai oleh siswa dalam proses pembelajaran, yaitu pengetahuan, pemahaman, penerapan, analisis, sintesis, dan evaluasi. Ranah pengetahuan termasuk ranah yang harus dicapai terlebih dahulu sebelum mencapai ranah selanjutnya.

Metode pembelajaran adalah prosedur, urutan, langkah-langkah, dan cara yang digunakan guru dalam pencapaian tujuan pembelajaran (Roestiyah, 2001). Adapun beberapa metode pengajaran bahasa asing yang dapat dipakai dalam pembelajaran bahasa Jepang (Padmadewi, 2012) yaitu (1) Grammar Translation Method adalah menerjemahkan kalimat dari bahasa ibu ke bahasa target atau sebaliknya, dan bahasa ibu digunakan sebagai bahasa pengantar di dalam kelas; (2) Direct Method adalah pembelajaran yang 
mengutamakan pada aspek berbicara peserta didik; (3) Audiolingual Method yaitu menekankan pada aspek pengucapan dan latihan-latihan pengulangan pola kalimat dasar dengan menggunakan drill secara berulang agar siswa mampu menirukan pelafalan, mengingat dan menghafalkan materi yang diberikan atau yang biasa disebut dengan mimicry memorization; (4) Total Physical Response yaitu menekankan pada kegiatan merespon dengan gerakan fisik, sehingga dituntut mampu merespon secara linguistik.

Strategi pembelajaran bahasa asing adalah perpaduan dari urutan kegiatan, cara mengorganisasikan materi pelajaran, peralatan dan bahan, dan waktu yang digunakan dalam proses pembelajaran untuk mencapai tujuan pembelajaran yang telah ditentukan (Suparman, 1997). Adapun strategi pembelajaran bahasa asing, yaitu (a) Diskusi yaitu interaksi antara siswa dengan siswa atau siswa dengan guru untuk memecahkan masalah, menganalisis, dan memperdebatkan topik tertentu (Aqib, 2014); (b) Kerja kelompok kecil yaitu siswa saling bertukar informasi dan belajar dari siswa lain dari perspektif yang berbeda, yang dilakukan dalam kelompok siswa (Padmadewi, 2012); (c) Menggunakan lagu dan permainan untuk meningkatkan minat siswa agar dapat menikmati proses pembelajaran di dalam kelas (Padmadewi, 2012); (d) Ceramah digunakan agar guru lebih mudah mengawasi ketertiban siswa dalam menyimak pelajaran (Padmadewi, 2012); (e) Aktivitas kinerja yaitu siswa diminta untuk memerankan suatu hal untuk melakukan sesuatu, bisa berupa debat atau roleplay (Padmadewi, 2012); (f) Drill digunakan untuk melatih peserta didik terhadap bahan yang telah diajarkan agar memiliki keterampilan dari yang sudah dipelajari dan dilakukan secara berulang (Roestiyah, 2008); (g) Tanya jawab adalah teknik mengajar dengan tujuan memberikan motivasi kepada siswa agar lebih aktif untuk bertanya (Roestiyah, 2001); (h) Pemberian tugas diberikan untuk mengetahui atau mengukur hasil belajar siswa serta dalam pemberian tugas perlu dilakukan evaluasi, tugas bisa dikerjakan di sekolah, di rumah, atau tempat lainnya (Roestiyah, 2008); (i) Information gap yaitu strategi pembelajaran yang membentuk perbedaan informasi yang dimiliki masing-masing siswa dan perbedaan tersebut dapat dihilangkan dengan cara bertukar informasi yang dimiliki (Danasasmita, 2009).

Menurut Matsumoto (2007), terdapat tiga tahapan dalam proses pembelajaran bahasa Jepang dasar, yaitu 導入 (dounyuu / latihan pengenalan), 基本練習 (kihon renshuu / latihan pengulangan), dan 応用練習 (ouyou renshuu / latihan penerapan).

Tahapan導入 (dounyuu / latihan pengenalan) merupakan proses pengenalan pemahaman makna dan bentuk, pengenalan yang dimaksud adalah tentang bagaimana cara seorang guru dalam memberikan materi kepada siswa. Untuk melakukan 導入 (dounyuu) terdapat dua cara, yaitu dengan menjelaskan pola kalimat dan menggunakan media.

Tahapan基本練習 (kihon renshuu / latihan pengulangan) merupakan kegiatan latihan pengulangan dengan cara mengucapkan kembali kosakata atau kalimat mengikuti contoh yang diberikan oleh guru. Latihan ini bertujuan agar siswa lebih bisa memahami dan mampu mengingat kosakata maupun pola kalimat yang diajarkan.

Tahapan応用綀習 (ouyou renshuu / latihan penerapan) merupakan latihan penerapan mengenai materi pelajaran bahasa Jepang yang telah diajarkan. Siswa dilatih untuk menggunakan materi yang diajarkan dalam kehidupan sehari-hari.

Tingkatan sekolah dasar umumnya dibagi menjadi dua, yaitu kelas rendah dan kelas tinggi. Kelas rendah terdiri dari kelas satu, dua, dan tiga, sedangkan kelas tinggi terdiri dari kelas empat, lima, dan enam. Menurut Matakupan (1994), kemampuan kognitif siswa sekolah dasar kelas tinggi sudah mengalami perkembangan dan memungkinkan mereka untuk merencanakan gagasan-gagasan yang bersifat konkret. Selain itu juga telah tumbuhnya daya konsentrasi siswa, tumbuhnya tindakan mandiri, bekerjasama dengan kelompok, memiliki rasa ingin tahu yang tinggi, adanya minat siswa untuk belajar, dan bertindak sesuai cara yang dapat diterima oleh lingkungannya.

Kemampuan kognitif siswa dipengaruhi oleh beberapa faktor, salah satunya adalah gaya belajar siswa. Terdapat beberapa jenis gaya belajar siswa, yaitu gaya belajar visual, gaya belajar auditorial, dan gaya belajar kinestetik. Ciri-ciri siswa dengan gaya belajar visual cenderung harus melihat bukti terlebih dahulu agar dapat mempercayainya, siswa dengan 
gaya belajar auditorial cenderung mengandalkan pada pendengaran untuk dapat memahami dan mengingat, sedangkan siswa dengan gaya belajar kinestetik cenderung harus menyentuh sesuatu yang memberikan informasi tertentu agar dapat mengingat (Uno, 2010).

Anak usia sekolah dasar berada pada tahapan operasional konkret yang berarti pada rentangan usia tersebut anak mulai menunjukkan perilaku belajar diantaranya (1) mulai memandang dunia secara objektif serta memandang unsur-unsur secara serentak, (2) mulai berpikir secara operasional, (3) menggunakan cara berpikir operasional untuk dapat melakukan koleksi benda-benda berdasarkan kriteria tertentu (4) mempergunakan hubungan sebab akibat (Kawuryan, 2011).

Seorang guru tidak hanya berperan sebagai teladan bagi siswa, namun juga sebagai pengelola pembelajaran. pembelajaran dikatakan berhasil apabila guru mampu memilih metode dan strategi pembelajaran yang tepat. Dimyati dkk (2002) menyatakan bahwa berhasilnya suatu pembelajaran tergantung bagaimana proses pembelajaran yang dialami oleh siswa. Masalah yang timbul dalam proses pembelajaran disebabkan kurangnya hubungan komunikasi antara guru dan siswa sehingga proses interaksi menjadi terhambat.

Sebagai seorang guru, tentunya akan menemukan kendala-kendala dalam proses pembelajaran. Untuk mengatasi hal tersebut dapat dilakukan upaya memperbaiki proses pengajaran. Selaku pengelola kegiatan siswa, guru juga diharapkan membantu dan membimbing siswa dalam proses pembelajaran.

Kendala-kendala yang biasanya dihadapi seorang guru adalah masalah ketika memberikan pengarahan kepada siswa, evaluasi dan penilaian, struktur atau urutan pembelajaran, penggunaan metode serta strategi yang salah.

\section{Metode}

Untuk mengumpulkan data yang diperlukan dalam penelitian ini, digunakan metode observasi, wawancara, dan dokumentasi.

Observasi yang dilakukan untuk mengamati dan mencatat langsung proses pembelajaran dari awal sampai akhir pembelajaran dengan menggunakan pedoman observasi kelas dan alat perekam gambar. Metode observasi dilakukan untuk memperoleh data terkait dengan strategi dan kendala dalam pembelajaran bahasa Jepang.

Wawancara dilakukan untuk mendapatkan data yang mendukung hasil. Wawancara yang digunakan adalah wawancara semi terstruktur dengan menggunakan format pertanyaan dan alat perekam suara digital.

Dokumentasi dilakukan untuk mendapatkan data yang valid dan diperlukan dalam penelitian. Data yang dikumpulkan berupa silabus, RPP, foto dokumentasi, dan yang lainnya.

Metode analisis data dalam penelitian ini menggunakan metode deskriptif kualitatif yang dilakukan sesuai dengan keadaan sebenarnya. Metode yang digunakan sesuai dengan teoriteori yang relevan dan bertujuan untuk mendapatkan gambaran tentang profil strategi pembelajaran bahasa Jepang di SD Saraswati Tabanan.

Teknik analisis data yang digunakan dalam penelitian ini dapat dibagi menjadi lima langkah, yaitu (1) tabulasi data yakni menggabungkan seluruh data yang sudah diperoleh; (2) reduksi data yakni pemilihan dan peringkasan data mentah; (3) deskripsi data yakni mendeskripsikan seluruh data yang diperoleh; (4) klasifikasi data yakni mengelompokkan data berdasarkan kategori tertentu sesuai dengan tujuan penelitian; dan (5) penarikan kesimpulan yang disesuaikan dengan temuan atau keadaan di lapangan.

\section{Hasil dan Pembahasan}

Data dalam penelitian ini diperoleh melalui observasi, wawancara, dan dokumentasi. Observasi dilakukan di kelas 4 SD Saraswati Tabanan sebanyak empat kali. Wawancara yang dilakukan adalah wawancara semi terstruktur untuk mengetahui lebih mendalam sasaran pembelajaran bahasa Jepang, strategi pembelajaran bahasa Jepang yang digunakan, faktor yang mendasari penggunaan strategi, dan kendala-kendala yang dihadapi dalam proses pembelajaran bahasa Jepang di kelas 4 SD Saraswati Tabanan. Dokumentasi dilakukan untuk memperoleh data berupa silabus, RPP, foto dokumentasi, dan data lainnya. 


\section{Sasaran Pembelajaran Bahasa Jepang di Kelas 4 SD Saraswati Tabanan}

Sasaran pembelajaran bahasa Jepang di kelas 4 SD Saraswati Tabanan yaitu agar siswa mampu mengembangkan keterampilan dasar berbahasa Jepang, yang meliputi aspek menyimak, berbicara, membaca, dan menulis.

Sasaran pembelajaran pertama dapat dicapai dengan melatih pendengaran siswa melalui latihan pengucapan kosakata atau kalimat secara berulang-ulang, kemudian siswa mendengarkan kosakata atau kalimat tersebut. Tujuannya adalah agar siswa dapat membedakan pelafalan dan makna dari kosakata maupun kalimat tersebut. Misalnya guru mengucapkan "kore wa nan desuka?" sambil menunjukkan sebuah penghapus, kemudian siswa menjawab "sore wa keshigomu desu" dikarenakan siswa dituntut untuk mampu mendengarkan yang disampaikan oleh guru, kemudian siswa menjawab menggunakan kosakata sesuai dengan yang telah dipelajari sebelumnya. Sasaran ini terlihat pada setiap kelas yang diobservasi.

Sasaran pembelajaran kedua yaitu pada aspek berbicara yang dapat dicapai dengan memberikan latihan pengulangan kosakata maupun pola kalimat yang dilakukan dengan drill dan tanya jawab kepada siswa tentang materi yang diajarkan. Selain itu, siswa ditekankan untuk mengucapkan salam dalam bahasa Jepang ketika bertemu dengan orang lain di lingkungan sekolah sesuai dengan situasi pada saat itu. Misalnya ketika pagi hari, siswa mengucapkan ohayou gozaimasu.

Sasaran pembelajaran ketiga yaitu pada aspek membaca yaitu agar siswa mampu membaca kosakata dan contoh kalimat bahasa Jepang yang terdapat pada buku penunjang, namun praktik ini tidak dapat diberikan kepada seluruh siswa melainkan hanya beberapa siswa saja dikarenakan alokasi waktu yang terbatas. Setelah membaca, guru meminta siswa untuk menerjemahkan kosakata maupun kalimat yang diberikan sehingga siswa tidak hanya mampu membaca, namun juga memahami makna dari kosakata dan kalimat tersebut. Selain itu, siswa juga ditekankan agar mampu membaca kosakata sesuai dnegan cara membaca dalam bahasa Jepang. Misalnya kata "desu" cukup dibaca "des".

Sasaran pembelajaran keempat yaitu pada aspek menulis. Walaupun pembelajaran di SD Saraswati Tabanan tidak menggunakan huruf Jepang, namun siswa diharapkan mampu menuliskan kosakata dan kalimat menggunakan huruf romaji (huruf latin) dengan baik dan benar. Sasaran ini dapat dicapai dengan memberikan latihan menuliskan kosakata dan kalimat di papan tulis sehingga apabila terdapat kesalahan guru akan langsung mengoreksinya. Misalnya ketika siswa melakukan kesalahan pada penulisan kosakata boorupen yang memiliki bunyi panjang, maka guru akan langsung mengoreksinya. Pada sasaran ini siswa hanya diharapkan mampu untuk menuliskan kosakata dan kalimat sederhana, belum sampai pada mengarang seperti yang dilakukan di SMA.

Dari pemaparan diatas, dapat disimpukan bahwa sasaran pembelajaran bahasa Jepang di kelas 4 SD Saraswati Tabanan pada umumnya sama dengan sasaran pembelajaran bahasa Jepang pada tingkatan yang lebih tinggi, yaitu agar siswa mampu mengembangkan keterampilan dasar berbahasa Jepang yang meliputi aspek mendengarkan, berbicara, membaca, dan menulis. Pembelajaran yang dilakukan pada tingkat sekolah dasar masih tergolong sederhana dibandingkan dengan tingkat sekolah menengah pertama (SMP) atau sekolah menengah atas (SMA), hal tersebut dikarenakan pada tahap usia sekolah dasar cara belajarnya berkembang secara bertahap dimulai dari hal yang paling sederhana sampai hal yang lebih kompleks.

\section{Strategi Pembelajaran yang Digunakan Guru Bahasa Jepang dalam Mengajar}

Dalam penyajian materi, guru melakukan tahapan proses pembelajaran bahasa Jepang dasar. Tahapan pertama yang dilakukan adalah 導入 (dounyuu / latihan pengenalan) yaitu dengan mengulang materi pelajaran sebelumnya. Tahapan kedua yang dilakukan adalah 基本練習 (kihon renshuu / latihan pengulangan) yaitu dilakukan dengan 文型練習 (bunkei renshuu / latihan dasar untuk melatih kosakata dan kalimat) yang terdiri dari 反復練 習 (hanpuku renshuu / latihan pengulangan) dan 応答練習 (outou renshuu / latihan tanya jawab). Tahapan ketiga yaitu 応用練習 (ouyou renshuu / latihan penerapan), namun tidak dilakukan dikarenakan alokasi waktu yang terbatas. 
Guru menggunakan audiolingual method dalam proses pembelajarannya, namun hanya sebatas pada latihan mengulangi apa yang diucapkan guru dalam bahasa taget (bahasa Jepang) dan agar siswa bisa menjawab pertanyaan yang diberikan oleh guru sekaligus akan berlatih menguasai pola kalimat bertanya dan menjawabnya dalam bahasa Jepang. Pembelajaran lebih didominasi dengan grammar translation method (GTM) dimana guru menggunakan bahasa Indonesia dalam menjelaskan materi, dan dalam pemberian tes guru lebih sering memberikan tes berupa menerjemahkan dari bahasa ibu ke bahasa target atau sebaliknya.

Adapun strategi pembelajaran yang digunakan oleh guru bahasa Jepang di kelas 4 SD Saraswati Tabanan yaitu strategi drill, tanya jawab, dan pemberian tugas.

\section{Drill}

Penerapan strategi drill sesuai dengan tahapan pembelajaran bahasa Jepang dasar yakni pada tahapan 基本練習 (kihon renshuu / latihan pengulangan). Dalam penggunaannya, guru melakukan kegiatan 反復練習 (hanpuku renshuu) dengan cara memberikan latihan pengulangan pengucapan kosakata maupun pola kalimat baru secara berulang hingga siswa dapat melafalkan kosakata maupun kalimat dengan benar serta dapat mengingatnya. Hal ini disebut dengan Mimicry Memorization yaitu metode pembelajaran yang ditekankan pada meniru kemudian diingat dan dihafalkan oleh siswa (Nuha, 2012).

Drill dilakukan dengan dua cara, yaitu dengan cara guru mengucapkan kosakata atau kalimat dalam bahasa ibu kemudian siswa menjawab dengan bahasa target atau sebaliknya, serta dengan cara menunjuk beberapa orang siswa ke depan kelas untuk menuliskan kosakata atau kalimat yang diberikan. Hal tersebut dilakukan karena kemampuan kognitif siswa yang berbeda-beda, sehingga dengan kedua cara penerapan strategi drill tersebut siswa mampu mengingat dan memahami materi yang dipelajari. Sejalan dengan temuan tersebut, Uno (2010) menyatakan bahwa perbedaan kemampuan kognitif siswa disebabkan oleh gaya belajar yang berbeda-beda antara satu siswa dengan siswa yang lainnya. Dari hal tersebut dapat diketahui bahwa sebagian besar siswa di kelas 4 SD Saraswati Tabanan memiliki gaya belajar visual, yakni siswa cenderung harus melihat bukti terlebih dahulu agar dapat mempercayainya, yang berarti dalam usaha mengingat dan memahami suatu materi siswa tidak hanya mengandalkan indera pendengaran saja, namun juga mengandalkan indera penglihatan. Contohnya yaitu ketika siswa menuliskan kosakata Shashin di papan tulis dengan benar, maka siswa akan mengingat penulisan dari kosakata tersebut.

Drill yang diberikan oleh guru masih tergolong sederhana, yaitu berupa menebak, menulis, dan membaca kata. Guru tidak menggunakan media gambar melainkan menggunakan benda-benda yang ada disekitar disesuaikan dengan materi pelajaran.

\section{Tanya Jawab}

Strategi tanya jawab yang diterapkan sesuai dengan pembelajaran bahasa Jepang dasar, yaitu pada tahapan 基本練習 (kihon renshuu / latihan pengulangan). Dalam hal ini guru melakukan kegiatan 応答練習 (outou renshuu) dengan cara melakukan tanya jawab dengan siswa agar interaksi antara guru dengan siswa sama-sama aktif. Hal tersebut sejalan dengan pendapat dari Djamarah (2013) yang menyatakan bahwa strategi tanya jawab merupakan strategi pembelajaran dalam bentuk pertanyaan yang harus dijawab terutama oleh guru kepada siswa atau sebaliknya. Strategi tanya jawab digunakan oleh guru dikarenakan dapat membuat siswa menjadi lebih aktif, dapat mengontrol kelas, dan kemampuan berbicara siswa akan terlihat.

Pelaksanaan strategi tanya jawab yang dilakukan di kelas 4 SD Saraswati Tabanan bukan lagi berupa "yes no questions", siswa sudah mampu merespon pertanyaan dari guru berdasarkan materi yang telah diajarkan sebelumnya. Pertanyaan yang diberikan masih berupa pertanyaan sederhana mengenai materi yang diajarkan dan guru lebih aktif bertanya untuk menarik perhatian siswa, sehingga penggunaan strategi tanya jawab ini belum sampai pada tahap "information gap" yaitu perbedaan informasi yang dimiliki oleh masing-masing siswa dan perbedaan tersebut dapat dihilangkan dengan cara bertukar informasi yang dimiliki. 


\section{Pemberian Tugas}

Pemberian tugas diberikan ketika kegiatan pembelajaran telah berakhir dan guru selalu mengoreksi tugas yang telah diberikan. Tugas yang diberikan berupa membuat contoh kosakata maupun kalimat sesuai materi yang telah diajarkan atau menjawab latihan yang terdapat pada buku pegangan siswa.

Sebelum kegiatan pembelajaran berakhir, guru mengintruksikan tugas yang harus dikerjakan oleh siswa dengan cara menuliskannya di papan tulis atau menjelaskannya secara langsung. Tugas dikerjakan oleh siswa secara individu. Dharma (2008) juga menyatakan bahwa pemberian tugas dapat merangsang siswa untuk aktif belajar baik secara individu atau berkelompok. Pemberian tugas cukup efektif mengingat alokasi waktu pembelajaran yang terbatas.

\section{Faktor yang Mendasari Penggunaan Strategi Pembelajaran Bahasa Jepang}

Melihat minat siswa dalam pembelajaran bahasa Jepang masih kurang dikarenakan siswa kelas 4 SD Saraswati Tabanan baru pertama kalinya mengenal dan memperoleh pembelajaran bahasa Jepang sehingga terdapat beberapa siswa yang berpendapat bahwa bahasa Jepang sulit dipelajari. Oleh karena itu guru menerapkan strategi-strategi yang mampu menarik perhatian siswa. Terdapat dua faktor yang mendasari guru menggunakan strategi drill, tanya jawab, dan pemberian tugas dalam proses pembelajaran bahasa Jepang. Yang pertama dilihat dari karakteristik siswa yang berbeda-beda, terdapat siswa yang pandai dan siswa yang kurang pandai sehingga guru harus mampu untuk melibatkan siswa dalam proses pembelajaran tanpa harus membedakan siswa satu dengan yang lainnya.

Yang kedua dilihat dari kondisi siswa dalam kelas. Keadaan kelas yang kondusif dan dapat dikontrol guru merupakan tujuan utama dalam mencapai tujuan pembelajaran yang diinginkan, serta pembelajaran akan sesuai dengan alokasi waktu atau RPP yang sudah dirancang sebelumnya. Strategi drill dan tanya jawab digunakan agar terciptanya interaksi antara guru dengan siswa sehingga suasana kelas menjadi aktif. Sedangkan pemberian tugas dilakukan ketika guru tidak sempat memberikan lebih banyak latihan di dalam kelas mengingat alokasi waktu yang terbatas.

\section{Kendala-kendala yang Dihadapi Guru dalam Mengajar Bahasa Jepang}

Dalam proses pembelajaran, tentunya guru menemukan kendala-kendala. Adapun kendala yang dihadapi oleh guru bahasa Jepang di kelas 4 SD Saraswati Tabanan yaitu kendala pemilihan bahan ajar dan kendala alokasi waktu.

SD Saraswati Tabanan menggunakan buku pelajaran bahasa Jepang yang disusun oleh pihak sekolah. Penyusunan buku pelajaran tentunya disesuaikan dengan silabus dan kurikulum yang berlaku. Tetapi pada kenyataannya, kurikulum yang diterapkan di sekolah tersebut adalah kurikulum 2013, sedangkan bahan ajar yang digunakan masih berpedoman pada KTSP (Kurikulum Tingkat Satuan Pendidikan). Selain itu, terlalu lama menggunakan KTSP menyebabkan siswa sulit untuk mengubah pola pikir dan kebiasaan belajarnya dimana siswa diberikan penjelasan materi terlebih dahulu oleh guru, sedangkan pada kurikulum 2013 siswa dituntut untuk lebih aktif dalam menggali informasi dan berpikir kritis. Walaupun demikian masih banyak siswa pasif dalam proses pembelajaran walaupun sudah diberikan stimulus oleh guru, dan siswa merasa bosan karena diberikan pekerjaan rumah setiap hari. Hal tersebut menyebabkan guru tampak kesulitan dalam mengimplementasikan langkah-langkah pembelajaran sesuai dengan kurikulum 2013.

Alokasi waktu yang terbatas juga menjadi kendala guru sehingga tidak bisa menjelaskan materi sepenuhnya kepada siswa dan strategi pembelajaran yang digunakan juga tidak berjalan dengan efektif. Agar mampu memahami kosakata dan pola kalimat yang diajarkan, siswa harus mampu melafalkan dengan benar kemudian dilanjutkan pada pemahaman makna dari kosakata maupun pola kalimat tersebut sehingga dibutuhkan waktu yang cukup lama untuk mencapai hal tersebut.

Untuk mengatasi kendala-kendala yang ada dalam pembelajaran bahasa Jepang, guru di SD Saraswati Tabanan mengadakan sharing dengan guru di sekolah dasar lainnya untuk mengetahui langkah-langkah penerapan kurikulum 2013 dalam proses pembelajaran. Selain itu, untuk mengefisienkan waktu agar sesuai dengan RPP (Rencana Pelaksanaan 
Pembelajaran) yang telah dibuat, kemudian pada materi pelajaran kosakata dan pola kalimat sederhana guru sering memberikan latihan di sekolah yang berupa drill dan tanya jawab, sedangkan latihan soal yang terdapat pada buku penunjang menjadi tugas atau pekerjaan rumah.

\section{Simpulan dan Saran}

Berdasarkan hasil penelitian, dapat disimpulkan sebagai berikut.

Sasaran pembelajaran bahasa Jepang di kelas 4 SD Saraswati Tabanan yaitu agar siswa mampu mengembangkan keterampilan dasar berbahasa Jepang yang meliputi aspek mendengarkan, berbicara, membaca, dan menulis.

Strategi pembelajaran yang digunakan oleh guru yaitu strategi drill dan tanya jawab yang dilakukan di dalam kelas, serta strategi pemberian tugas yang dilakukan ketika kegiatan pembelajaran telah berakhir.

Adapun faktor yang mendasari penggunaan strategi pembelajaran dalam kelas adalah karateristik siswa dan kondisi siswa dalam kelas, dikarenakan karakteristik dan kemampuan siswa yang berbeda-beda serta agar terciptanya suasana kelas yang kondusif sehingga pembelajaran sesuai dengan alokasi waktu atau RPP yang telah dibuat.

Kendala yang dihadapi guru dalam mengajar bahasa Jepang yaitu kendala dalam penggunaan media pembelajaran dan kendala alokasi waktu. Hal tersebut dapat diatasi dengan menggunakan benda-benda dalam kelas sebagai media pembelajaran, disesuaikan dengan materi pelajaran. Kemudian agar dapat mengefisienkan waktu, guru memberikan tugas atau pekerjaan rumah kepada siswa sehingga guru dapat menjelaskan materi pelajaran dengan maksimal.

Berdasarkan temuan yang ditemukan dalam penelitian ini, guru bahasa Jepang di SD Saraswati Tabanan diharapkan mampu menggunakan strategi yang bervariasi dan media pembelajaran lainnya agar minat siswa dalam belajar bahasa Jepang meningkat dan menciptakan suasana kelas yang menyenangkan. Selain itu juga diperlukan untuk mengadakan penelitian sejenis, yang dapat dijadikan acuan dalam pemilihan strategi pembelajaran yang digunakan di dalam kelas, khususnya strategi pembelajaran bahasa Jepang pada tingkat sekolah dasar.

\section{Daftar Pustaka}

Aqib, Zainal. 2014. Model-model, Media, dan Strategi Pembelajaran Kontekstual. Bandung: Yrama Widya.

Danasasmita. 2009. "Guru Bahasa Jepang di Indonesia Peluang dan Tantangan". Tersedia pada http://file.upi.edu/operator/upload/pdf (diakses tanggal 17 April 2018).

Dharma, Surya. 2008. Strategi Pembelajaran Dan Pemilihannya. Jakarta: Departemen Pendidikan Nasional.

Dimyati, dkk. 2002. Belajar dan Pembelajaran. Jakarta: PT. Rineka Cipta.

Djamarah, Syaiful Bahri dan Aswan Zain. 2013. Strategi Belajar Mengajar. Jakarta: Rineka Cipta.

Dimyati dan Mudjiono. 2006. Belajar dan Pembelajaran. Jakarta: PT. Rineka Cipta.

Kawuryan, Sekar Purbarini. 2011. "Karakteristik Siswa SD Kelas Rendah dan Pembelajarannya". Tersedia pada http://staffnew.uny.ac.id/upload/132313274/pengabdian/KARAKTERISTIK+DAN+CAR A+BELAJAR+SISWA+SD+KELAS+RENDAH.pdf. (diakses tanggal 17 April 2018).

Matakupan, J. 1994. Program Pendidikan Usia Sekolah. Bandung: Tri Pitaka.

Matsumoto, Isao. 2007. Shokyuu o Oshieru. Tokyo: The Japan Foundation.

Nuha, Ulin. 2012. Metodologi Super Efektif Pembelajaran Bahasa Arab. Yogyakarta: Diva Press.

Padmadewi, Ni Nyoman. 2012. Strategi Pembelajaran. Singaraja: Undiksha Press.

Roestiyah. 2001. Strategi Belajar Mengajar. Jakarta: Rineka Cipta.

Roestiyah. 2008. Strategi Belajar Mengajar. Jakarta: Rineka Cipta.

Suparman, Atwi. 1997. Model-Model Pembelajaran Interaktif. Jakarta: STIALAN.

Uno, Hamzah B. 2007. Profesi Kependidikan. Jakarta: Bumi Aksara. 
JPBJ, Vol. 4 No. 2, Juli, 2018

ISSN: 2613-9618

Uno, Hamzah B. 2010. Orientasi Baru dalam Psikologi Pembelajaran. Jakarta: Bumi Aksara 